\title{
Thanksgiving songs in contemporary Pedi society
}

\begin{abstract}
This article is the dissemination of an investigation of the Pedi tradition of Thanksgiving Songs that continued in spite of all cultural suppression. This article discusses the form, content and functions of Pedi Thanksgiving Songs as guided by the research questions and hypothesis of the study. Content is discussed with reference to African indigenous knowledge about what a 'human-musical product' entails in the African world view. It is a creative-artistic content informed by human, philosophical, artistic, spiritual, socio-contextual, and health perspectives indigenous to Africa. The particular Pedi Thanksgiving Song discussed here serves as an example and/or representation of the general African traditional perspective of musical practice and creativity. Specifically, the study attempts to establish the reality that music making is not restricted to organized sound only; it also includes a symbolic expression of a social and cultural organization, which reflects the values, the past and present ways of life of human beings.
\end{abstract}

\section{A. INTRODUCTION}

\section{Christianization of African meta-religious/musical powers}

Western influence has come to South Africa through the normal processes of cultural encounter with people of different cultures. Cultural change usually takes place over an extended period, but in Africa acculturation ${ }^{2}$ is taking place at tremendous speed. The intervention of Christian missionaries in the Pedi community resulted in some Pedi people observing the hymns introduced by the missionaries and forgetting about their indigenous songs (Moila 1988:111ff; 152ff; 189ff). In some extreme cases, there has been total replacement of the Pedi Thanksgiving Songs with Christian hymns and gospel music ${ }^{3}$. The impact of such change is staggering and difficult to contemplate. How does one, for instance, fathom the effects of missionary prohibition of dance in a culture where dance is so prominent in the day to day being of the people - so integral to their behaviour - be it at work, play, recreation, devotion or creating art...? The missionaries avidly suppressed dancing in church, so that Africans were forced to stand still while singing the European hymns. Dancing had no place in European church worship and missionaries were imbued with Victorian era ideas of its 'sensuality' and 'sinfulness' (Smith 1987:6). As African people began to respond to the gospel, they were forced to abandon their ancient customs, rites, cultural identities, and even their names because all of these were regarded as "pagan".

1 Post Doctoral Research Fellow in Biblical and Religious Studies at the University of Pretoria with prof DJ Human.

2 Acculturation implies culture change through assimilation and hybridization, whereby 'culture A' invades 'culture B' through religion, music, language, dance, attire, etc.

3 Aleaz (2003:107) emphasizes that the Christian churches continue to manifest their colonial heritage today in different ways: in the style and functioning of their bureaucracy; in the shape of their worship; in the language and content of their theology; and in the way in which all these are tightly controlled by a central authority, European in its mentality, that allows little local autonomy and is insensitive to local needs. 
In these crucial, initial encounters with the powerful Western missionaries, the African people were made to feel inferior. Their way of life was condemned as totally bad.

The attitude of these early missionaries showed an unwitting ignorance of the positive values of the African way of life. Their actions were an unwarranted attempt to control the social situation and an unfounded attack upon the fundamental institutions of the traditional African society. Without first trying to understand the significance of traditional rituals, missionaries condemned most rites of passage and social ceremonies as pagan, whether they were contrary to the teachings of the scriptures or not. In the eyes of the African people, the missionaries' attitude was one of total hostility toward traditional culture and religion. Countless customs and institutions of many tribes have come under the direct assault of the missionaries. In their fury to purge the society of all paganism and to avoid syncretism, early missionaries condemned not only "black" magic, sorcery, and witchcraft, but also the ageless practices in African traditional life without thorough examination, for example, the education and training, which is given during initiation, and is vital for the community's maintenance of self-understanding. The fundamental significance of initiation for the total African cultural life was not fully realized by most missionaries (Mugambi 2005:532). For some of the missionaries, the practices were considered to be unnecessary ordeals, causing great suffering to the adolescents.

When missionaries rejected tribal institutions, they created "cultural voids" within the society, since the functions served by the prohibited social customs were no longer fulfilled. Many indigenous forms of expression were caused to be bypassed, as they were regarded as childish, or ridiculed by missionaries. Because they did not understand the symbolic logic of the forms, they regarded them as a hindrance to progress. Nothing was offered to fill the vacuum which was left by the destruction of traditional customs.

Added to the government's neglect of developing indigenous music is the historical influence of Christian missionaries among the Pedi people. Missionaries saw drumming as woven into the fabric of pagan life, so they were determined to exorcise it. Despite the scarcity of instruments, Bapedi refused to forsake their musical traditions and an outstanding vocal musical culture evolved. Drums are among the limited number of musical instruments found in Limpopo Province, especially amongst the Pedi speaking people.

African music was regarded as not sufficiently artistic and spiritual by the missionaries. The majority of the people appear to have lost interest in their traditional music and musical instruments as a result of contact with modern civilisation and the influence of missionaries. Missionaries have taught them to regard their own musical traditions as inferior and to accept Western church music instead. Christian activities were brought into Africa together with the main colonial activities; both were closely linked, and they were of course, foreign.

The dilemma that arose in the Pedi community and which is still current to this day is how to strike a balance between the traditional and the modern; how to balance deep indigenous perspectives with regard to form, content, organization and performance of Pedi indigenous music, with new ones encountered in cultural imports from the West. The dilemma has given rise to three categories of protagonists: traditionalists, semi-traditionalists and modernists ${ }^{4}$.

In view of the above scenario, it becomes necessary to address the relevance of Pedi Thanksgiving Songs in the modern context. Consequently, the study concerns itself with the major research question: Which peculiar structural elements constitute the form, theoretical content and performance of Pedi indigenous music? In order to obtain detailed data, the following subsidiary questions were formulated and considered: (a) How did the indigenous Pedi

4 While traditionalists advocate traditional organization and performance of Pedi indigenous music, semitraditionalists mix the modern and the traditional, and modernists have done away with traditional music altogether. 
practice of Thanksgiving survive; and (b) How did the indigenous Pedi practice of Thanksgiving relate to what the missionaries were proclaiming and doing in the church context?

\section{Theoretical Framework}

The study is based on the theory of aesthetic functionalism as proposed by Akuno (2005:160) which views the meaning of music as being rooted in the role music plays in the life of those who make it. Just as the author puts it, the functionalists attribute the meaning and value of a work of art to its relationship with the activities of the society. As a work of art, the value of Pedi Thanksgiving music is therefore judged from society's involvement with and in it; and consequently the role or function that it performs in that society's existence. Since this article seeks to establish the role of Pedi Thanksgiving Songs in the Pedi society, hence the applicability of the aesthetic functionalism theory. The data for this research was collected through oral interviews. Five performing groups were purposively sampled to provide the much needed information on Pedi Thanksgiving Songs.

This article theorizes that: a) In Africa music is used to invoke, venerate, appease and entertain the supernaturals and hence the supernaturals are concerned about which types of music are played, and their composition and performance practices; b) In Africa, music and the inspiration to compose it are also received from meta-musical i.e. metaphysical or spiritual sources; and c) There is no way the artistry of an African music composer can be totally separated from his spiritual background and experiences.

Finally, this article is a corollary to both the question and answer raised by DjeDje (2003:vii): What gives African music its power? In my view, it is critical to understand the nature, essence and underlying theoretical and humanistic principles of African music because this may explain why people are attracted to the music.

\section{Pedi musical terminology and conceptualisation}

Pedi traditional musicians do not think or speak about music in European's ways. Terminology is concrete and people-orientated, not abstract and by definitions. Music is an abstract idea, songs are something done by people. Participants learn by observation and imitation. There is little or no detailed teaching as in western music pedagogy. People learn to grasp things as a Gestalt - an experiential whole. Some traditional terms do relate fairly directly to European terms: hlabelela, to lead a song; latela, to follow a song. These terms directly refer to call-and-response technique. Furthermore, some traditional terms imply style elements. For example, the Pedi term malopo refers to the music of spirit possession. Malopo is a complex term, at root it describes the event of a spirit possession, where a healer will perform malopo songs. This word also refers to an affliction, as in the disease or problem that is troubling the patient. In addition, malopo is a genre of music that accompanies malopo events. The terms mogobo and motholoane are both Wisdom and Thanksgiving Songs. These songs are sung by men only. Women are not allowed to sing them. In the Pedi society like in many African societies there are musical types for children, for men, and for women. Where a musical type is meant or rather prescribed for men, women do not participate in its performance; neither do men participate in musical types for women. Words of songs refer to rules and customs which have to be kept at all cost. They contain a lot of wisdom in as far as virtues (which are related to ideal humanistic creativity, sensibilities and meanings), are concerned. They therefore, embody the African philosophy of life, achievement and identity. A lot of ideas may be borrowed from virtues/lessons and philosophies embedded in the cultural practices. Music, therefore, being held high among the African societies, plays a role of training and preparing the individuals to understand their societies and themselves better for the survival of the human race (Orawo 1998:142). Through the singing of mogobo, 
motholoane and malopo 5 songs, in the Pedi culture the aim is to preserve and uphold traditional Pedi culture. In these songs repetition is a powerful, forceful, rhetorical and expressive device skilfully employed by the singers to hammer key words home, in order to implant dominant emotions in listeners' minds. Repetitions often appear in forms of chorus refrain or a frequent return of the narration to the principal idea at strategic intervals. However, there are some western musicological concepts which are very difficult or impossible to express directly in traditional Pedi. They are ideas such as intervals and scale, rhythm, and many others.

\section{B. DISCUSSION AND OBSERVATIONS}

\section{Thanksgiving songs (e.g. Kgoparara)}

Singing is by far the most prevalent mode of musical expression among the African people. Although genres of "instrumental music" exist, no such genre completely excludes song (Chernoff 1979:37; Oehrle \& Emeka 2003:39). Many formal and informal activities are marked by singing, whether or not the occasion is designated a "musical occasion". Although there are certain amounts of private, solo singing, the Pedi people regard singing as essentially a group activity 6 , an opportunity to express their "communal ethos".

In the Pedi culture social and ethical values are communicated through Thanksgiving Songs, while the content is largely dictated by current concerns and the way people approach them. It is important to take note of the fact those musical cultures and societies in Africa are guided by complex sets of moral and ethical values and beliefs which have evolved with time and are deeply embedded historically and culturally in the psyche of the African people, both collectively and individually. Values are lived (normatively), perceived (in ourselves and others) and exhibited (as in a way of living, dress, or music), (Mans 2005:16). Pedi Thanksgiving Songs provide opportunities for people to express their interpretations of society. The narrator holds the listeners' attention, adding another dimension to the story through singing, dancing and ritual intent - a symbolic one, thereby creating a deeply transformative event that is crucial to the well-being of the people.

Pedi music is highly syllabic, in that each syllable is often assigned to a tone, with little use of slur expressions involving only two or three pitches to colour sustained tones or movements in the melody. The use of these slur expressions are primarily applied to link syllables, either at the beginning or at the end of phrases. Pedi musicians consider the language flexible and therefore treat the text as such in the melodic craftsmanship. The basic philosophy behind the syllabic treatment is to allow constant flow of communication, since narratives require much use of words. In the following song, Kgoparara, the traditional healers are expressing their appreciation and thanksgiving to the ancestors. The use of call and response in the following song is seen as a performance style, non-comparable to the European verse form. It is more of a performance style than a structural form, because a solo performance of the same piece does not show incompleteness of any sort. It only shows the complementary phrasing of the song itself, which in a group performance may be presented in complementary call and response style for aesthetic and labour distribution purposes.

\section{Text and translation}

1. Bo tate, go ja re jele

Our forefathers, we have enjoyed the meals

5 In brief, the term malopo refers to an illness called malopo which can only be terminated by a ritual called malopo, accompanied by the ngaka (doctor) of malopo.

6 Among the Pedi people music also provides an opportunity for interpersonal relations. 
2. E fela re nyaka nama

But we are still in need of the meat

3. Re tsoma ga go nona

We would appreciate if you give us enough meat full of fat

4. Ga gešu motse o agwa ke basadi

According to our culture, the household is built by women

5. Banna ba fedile

All men have passed away

6. Nka be e sa le botala

If it was long time ago

7. Nkabe ke bitšwa "Kgobadi" pholo ya mmala

I could be described as "Kgobadi" the coloured oxen

8. Mpiletšeng Tšhumu

Please call me "Tšhumu'.

9. Ramapantele se alafa batho

"Ramapantele", the traditional healer

10. Mpiletšeng "Tšhumu'

Please call me "Tšhumu"

11. Ramapantele, ngaka ya mošimanyana

"Ramapantele" the young traditional healer

12. Nkabe e sa le botala

If it was long time ago

13. Nkabe ke bitšwa mmate, mokane

I could be described as a friend indeed

The song was recorded by the author on a field trip at malopo ritual held at Dingwane village, Sekhukhune area in the Limpopo Province in May 2003.

\section{Music as community}

Singing plays an important role in the Pedi life. Van der Hooft (1979:150) infers that to the people of Africa dancing and music making serve as a means by which they relax and enjoy themselves. In Africa dance and music are essential elements of life ${ }^{7}$. Pedi musicians perform prophetically by foretelling the future consequences of certain actions taken by men and women

7 Hammond (2004:105) maintains that music, which acts partly on a conscious and partly on an unconscious or emotive level, is therefore frequently a way to articulate those aspects of our character of which we are not consciously aware. 
in the society during the past and present. In their foresight they investigate, evaluate, probe and foretell future events. In the Pedi culture there are fixtures at appropriate times of the year for religious festivals dedicated to the ancestors. There are also other annual religious rites of mass purgation, regeneration and thanksgiving.

Pedi communal musical performance is a clear expression of shared social characteristics and ideals, and hence is a setting for social formation. The application of musical thought as an integral part of culture confronts people with social reality. Through musical thought ${ }^{8}$ they come to have a better understanding of their society, and even actively shape it.

Songs as expression of appreciation and thanksgiving prevail in Pedi society to this day. Appreciation is indeed an important part of the tribe's act in general. Music serves as an adjunct to religion, and is used for happy and sad occasions, for expressing ideals and emotions, and romantically, for describing scenery (Kofie 1994:99). In improvised verses and precomposed songs, the Pedi single out those members of the community noteworthy for their accomplishments: matona (headmen) and other political figures and their descendants. They also include wealthy members of the community who are actively involved in the community development of the Pedi people. The Pedi society employs thanksgiving songs to rally warriors tuning up their morale, and generating public sentiments or moral support as well as pleasing their ancestors. At some festivals which have primary political orientation, thanksgiving songs are sung to celebrate and commemorate the founding of a community.

\section{The Context of Performances}

Many arguments about indigenous music approaches concern the need for and role of context. Sharing this view, Walker (1998:55) opines that in many cultures, music and its associated educational practices are seen as more integral to the total life style, not something extrinsic. In this song text singers who are traditional healers are communicating directly with their ancestors. The text and melody play complementary roles in the communication process. The singers make use of words that are sometimes suggestive of double or multiple meanings. These conceptual words often form the basis for the themes and sub-themes in the song.

The text falls into six clearly-defined sections: a) recognition of the deeds of ancestors (line 1 ); b) request and expressions of the singers' confidence in the ancestors (lines 2-3); c) tone of loneliness and frustration (lines 4-5); d) recognition of a traditional healer 'Tshumu' who trained the singers to become traditional healers (lines 8-11); and f) imagery (lines 12-13).

The introductory statement (line 1) poetically announces the recognition of ancestors' deeds 'Bo tate, go ja re jele' ('Our forefathers, we have enjoyed the meals'). The tone of the singers from line 2, 'e fela re nyaka nama' ('but we are still in need of the meat') and line 3, 're tsoma ya go nona, lekhura le kae' ('We would appreciate if you give us enough meat full of fat') presents a dissatisfaction that the singers (traditional healers) are still in need of more meat full of fat. The message communicated to the ancestors by the singers is that they are thankful, but they would appreciate it if the ancestors could offer them some more meat. The belief that ancestors will respond positively includes a request as well as the singers' confidence in the ancestors.

In this song we observe the careful use of figurative words with powerful associative meaning. The text possesses variation in poetic expression. The singers make use of several figures of speech, forms of imagery, idioms, parables and proverbs that require contemplation - serious thinking that demands insider knowledge of the Pedi language to fully comprehend the meaning of the song. This is evinced in the fourth line which remarks that 'according to our culture, the household is built by women', and fifth line 'all men have passed away'. The tone

8 Musical thought not only promotes social cohesion, but communicates many messages through song texts and dance features (Kruger 1999:124). 
in lines 4 and 5 reflects loneliness, despair and frustration because all men in the community have died. Taking melancholy of the lyrics into consideration, the focus in these two lines ( 4 and 5 ) is on relationships, the loss of men in the community and the frustration experienced by the bereaved families.

Most themes in this song are derived from the sense of realism rather than from idealism. Songs such as 'Kgoparara' are normally composed as reactions or responses to the realities of life (e.g. inauguration of the chief) that unfold in the Pedi society from time to time. They therefore had to reflect things that had occurred, which the musicians/traditional healers had seen or heard. The song recognizes the traditional healer 'Tshumu' (lines 8-11) who trained all the singers to become traditional healers. Because of the trust the singers (traditional healers) have in their mentor ('Tshumu'), as a signal of respect they call him with his praise name 'Ramapantele', (line 1). It is not clear why they are calling 'Tshumu'. It is possible that they might be calling him with the sole purpose of thanking him for the good work he has done in training them to become traditional healers.

\section{Music as expression}

Thanksgiving Songs in the Pedi culture express sincere thanks to the ancestors after every achievement, whether it is a good harvest or a patient's full recovery, etc. However, songs such as mogobo and motholoane may be sung for celebrating victory after every achievement. Thanksgiving Songs are sung to thank, please and praise ancestors after having responded positively to the community's requests. Similar rituals take place in thanksgiving after harvest, a very festive occasion, especially if the harvest has been a good one (Bourdillon 1976:303). The thanksgiving ceremony includes feasting on the meat of oxen killed by the chief for the occasion. If the spirit guardians have failed to provide a good harvest the previous year, they are not so lavishly honoured and the celebrations cease.

Music is such a powerful medium in the Pedi society that even history and tradition are preserved in song. Oral tradition is the basic means of transmitting ideas to the next generation. The above observation is supported by Mugambi (1989:94) when he states that the African cultural and religious heritage was passed on orally from generation to generation and the wisdom of the ancestors was conserved, not in written books, but in songs and oral traditions.

\section{The main findings of the current study are that:}

1. The form and content of Pedi Thanksgiving Songs is characterized by musical creativity and practice achieved through "performance-composition", which according to Nzewi (1991; 1997 and 2003), is the art of musically marshalling, interpreting and aesthetically enriching the ongoing events as well as contingencies of a performance context. Taking this into consideration from a music educator's point of view, individual and group creativity centred around narration and enhanced with music (including singing and dancing) should be provided for in a music curriculum. The focus should be on talent nurturing along with fostering appreciation and preservation of cultural heritage.

2. Pedi Thanksgiving Songs are deeply rooted in myths, taboos and beliefs that form basic philosophical foundations of the Pedi cultural fabric and hence its context-utilitarian nature. Therefore, in order to appreciate the relevance of African music, teachers and students need to be cognizant of its cultural underpinnings.

3. The solo-and-response form is the basic structural feature of Pedi indigenous music. However, in actual performance it was observed that there is no strictly fixed framework of music and/or text as is the case in western music. The thematic developmental aspect of the music is based on spontaneity, extemporization and creativity. Consequently, it 
is crucial for the Westerner to understand forms, structures and performance styles of African music. This dimension links the music to meaningful expression within a particular cultural setting.

4. The performance of Pedi Thanksgiving music, dance and drama complement each other in the process of communicating certain contextual messages. Therefore, music, dance and drama/theatre should be integrated under one umbrella in African arts and culture programmes. This is because the three units (in the context of African musical performance; theory and practice; and as expressed in the research on Pedi Thanksgiving music), form an integrated whole and cannot be split off from another.

With regard to the foregoing, this study supports the notion that African traditional music, as Nzewi (1997:11) puts it: "contains all materials that are needed in philosophy, theoretical content and principles of practices for culturally meaningful and independent modern music education of any disciplinary specialization at any level in Africa and perhaps elsewhere".

\section{Survival of the indigenous Pedi practice of thanksgiving}

Barrett (1968:89) indicates that the missionaries, as apologists of the faith, failed to relate the new faith to the old way of life. Barrett also says that this can be summarized as a failure in sensitivity. Early missionaries did not demonstrate a sensitive understanding of the society, religion, and psychology of the African people. Fullness of the biblical concepts of love, understanding and treating others as equals was not evident in missionaries' actions. Rather than allow the scriptures to guide in these matters, they formed opinions about the culture and proceeded to act upon them. As Barrett further notes: "In this failure missionaries were unfaithful to their own basic principle of appeal to scripture for guidance in situations new and old".

Cultural diffusion brought about by Christianity deterred the practice of Pedi traditional music. They did not recognize links between biblical faith and traditional society. In spite of the above detrimental factors, Pedi indigenous music (for example, Pedi Thanksgiving Songs) survived. This music survived because of the purpose it serves among the Pedi people at large. Pedi people use Thanksgiving Songs for ancestor veneration; for generating public sentiments or moral support; as well as to celebrate and commemorate the founding of a community. Alternatively, people who were not satisfied with the influence of Christianity on their culture formed African Independent Churches where their culture was better catered for. However, Pedi indigenous music did not survive in the whole of the Sekhukhune region. It survived mainly in and around remote areas where Pedi tradition is deeply rooted in ancestor veneration.

Furthermore, in spite of this culture climate, Pedi Thanksgiving Songs have proved to be a rigorous body of music embodying processes of social control that are worth preserving for the benefit of contemporary and future society. In the present state of world affairs, with change and destruction catapulting ahead, one senses the urgent need to step up action to preserve and ensure the continuation of our indigenous musical heritage in documentation and practice; cultural meaning may be lost as a result of current ongoing acculturation taking place in the organization and performance of Pedi indigenous music.

\section{Relationship between indigenous Pedi practice and Christian tradition of thanksgiving}

In both Christian tradition of Thanksgiving and Indigenous Pedi practice the divisions of individual and communal thanksgiving are found. However, Old Testament psalms emphasize the individuals' response to God's acts in the presence of their religious community (e.g. Pss 22; 40; 41 and 118). Pedi Thanksgiving Songs on the other hand pronounce communal aspects (e.g. kgoparara). Responsorial devices are detectable in selected psalms as well as in Pedi 
Thanksgiving Songs. Among Pedi people, particularly, during communal rites singing is often done in a responsorial manner between the leader and the participants. A marked distinction between both traditions is noted. Whereas psalmists direct all their thanksgiving to God, Pedi people on the contrary address their ancestors.

\section{A SAD TREND}

Having achieved the main objectives of this article, it is sad to note from observations that a significant amount of the original traditional stuff is no more to be found in the Pedi society and in some other African countries. This is because the traditional religious institutions and heritage that host the real traditional religious and musical practices are dying out due to influences of Western education, foreign religions and socio-economic problems. The few practitioners at 'home' are no more diligent in keeping the traditions. Due to socio-economic hardships, they have desacredized vital aspects of the legacies by taking some of the practices out of their original contexts in order to satisfy foreign inquirers and hence compromise their cultural heritage for monetary gains. Martey (2003:128-129) endorses this observation by stating that African liberation theology sets Africa's socio-economic and political struggle within a theological context. He further insists that it defines poverty in anthropological terms and draws attention to all structures - political, economic, ecclesial, religious - that dehumanize and impoverish the African created in the image of God.

Apart from theses and dissertations in African Universities and few local documentation projects, the development, promotion and documentation of traditional African religious and musical cultures are being carried out and sponsored by Euro-Americans, on their soil and for their use. There is a kind of injustice here. The West 'sold' Christianity to Africans and not only condemned but made them throw away their traditional religious and musical heritage, only for them to come back now to be demanding for what they had once made Africans throw away.

Religious and Music Education curricular in Africa, especially in South Africa is still largely Western oriented, thus putting traditional African religion and music at a disadvantage. Currently, the system therefore produces students that know little or nothing on their traditional religious and musical heritage and practices.

It is speculated that in the nearest future, the remnant and modified versions of real traditional African religious and musical practices would only be found in Western research institutions and among neo-traditional African performers (outside Africa) and among Africans in diasporas such as African Americans, Cubans, Brazilians and Caribbeans.

\section{CONCLUSION AND CHALLENGES}

Considering the aesthetic quality of compositions by African art composers and considering the meta-musical dimension and the message therein, it can be concluded that African art music can still be fully artistic while at the same time functional on a psycho-spiritually level. I think there is nothing wrong with this. We even need more of this now that there is increased need for what I have theorized as 'transformative musicality'.

Arising from the findings and the conclusion of this article, there is the need for Africans to keep, uphold and promote their meta-religious/musical heritage and refuse to sell it out in the face of intimidation, racial prejudice, discouragements and socio-economic hardship. This is because in developing their arts, their spiritual empowerment needs be strengthened. As a way of redeeming the loss and reviving the heritage, it is recommended that traditional African religions be taught as a subject in both primary and post-primary institutions. Scholars and 
researchers in African music, African religions and African Studies in general, should also as a matter of urgency, undertake research and document the primitive nitty-gritty of the veneration of the supernaturals in the Ancient Africa.

The final challenge here is the need for Africans to redirect and remobilize their metaphysical forces and legacies to better their lives. Power used selfishly, i.e. 'diabolic spirituality' always lead to destruction of lives and properties, reduces corporate greatness and lead to perpetual backwardness, while positive use of power always fuel societal corporate strengths, greatness and prosperity. This is the greatest challenge of the time.

\section{E. RECOMMENDATIONS FOR FURTHER RESEARCH}

As expressed in this study, Pedi Thanksgiving music, being a traditional music, is difficult to be done away with. Therefore, the department of Arts and Culture in South Africa and by extension, in other African countries, should encourage preservation of traditionally/culturally loaded communicative/informative practices by documenting them in a scholarly manner, as exemplified in the present study, for future reference, posterity and sustainable humanistic developments. As Akuno (2005:74) puts it, "today's state and activities provide the grounding and roots for tomorrow's achievements, the strides of which are determined by the level of understanding of 'today' that we can reach".

A study should be done on the form and content of other traditional Pedi musical arts and practices such as: wedding music, funeral music and harvest music with a view to examine in detail, their theory and practice in the context of indigenous and/or contemporary African humanistic, creative, artistic and theoretical thoughts and practices. Moreover, and related to the former, aesthetics in Pedi verbal arts such as: proverbs, epic, lyrics, dictums and other poetic formations should be examined in relation to how they are musically theorized, and practised.

Since the study was limited to the Pedi community, and hence may not have adequately reflected features in other African communities, a comparative study based on the form and content of indigenous music of other African communities should be carried out. In this connection, it is also noteworthy that research on aesthetics of other African cultural and artistic practices inclined to human development spheres such as entertainment, leisure, spiritual, social, philosophical, historical and psychological matters could be followed through.

\section{BIBLIOGRAPHY}

Akuno, E. A. 2005. "The role of research in Music Education”. In East African Journal of Music. Issue No. 1:64-77.

Aleaz, K. P. 2003. Introducing theologies of religions. Asia Journal of Theology 17(2), 442-459.

Barrett, D. B. 1968. Schism and Renewal in Africa. Nairobi: Oxford.

Bourdillon, M. F. C. 1976. The Shona Peoples: An Ethnography of the Contemporary Shona, with special reference to their religion. Gwelo: Mambo Press.

Chernoff, J. M. 1979. African Rhythm and African Sensibility: Aesthetics and Social Action in African Musical Idiom. Chicago: University of Chicago Press.

DjeDje, J. C. 2003. 'Four Words', in Anri Herbst, Meki Nzewi \& Kofi Agawu (eds.) Musical Arts in Africa:

Theory, Practice and Education. Pretoria: Unisa Press.

Hammond, N. 2004. 'Singing South Africannes: the construction of identity among South African youth choirs'. In Anri Herbst \& Hetta Potgieter (eds.) Journal of the Musical Arts in Africa. Volume 1, $103-$ 115. Cape Town: University of cape Town.

Kofie, N. N. 1994. Contemporary African Music in World Perspectives. Some Thoughts on Systematic Musicology and Acculturation. Accra: Ghana University Press.

Kruger, J. 1999. 'Singing Psalms with owls: a Venda twentieth - century musical history'. African Music, 7 
(4): $122-146$.

Mans, M. 2005. 'Aesthetics and values as core determinants of musical identity formation'. In Anri Herbst

(ed). The Musical Arts in Africa. Volume 2, 1-22. Cape Town: South African College Music.

Martey, E. 2003. African Theology. Enculturation and Liberation. Maryknoll, New York: Orbis Books.

Moila, M. P. 1988. Toward an Anthropologically Informed Theology: The Kingdom of God Theology,

Christian Presence, and Conflict in Pedi society. PhD thesis. (U.M.I. Dissertation Information service).

Chicago: Lutheran School of Theology.

Mugambi, J. N. K. 1989. African Heritage and contemporary Christianity. Nairobi: Longman Kenya. 2005. 'Christianity and the African Cultural Heritage'. In Ogbu U. Kalu (ed). African Christianity. An African story, 516-541. Pretoria: University of Pretoria.

Nzewi, M. 1991. Musical Practice and Creativity: An African Traditional Perspective. Bayreuth: IWALEWAHaus: University of Bayreuth. 1997. African Music: Theoretical Content and Creative Continuum: The Culture Exponents Definitions. Olderhausen, Germany: Institut fur Didaktik Popularer Musik. 2003. "Acquiring Knowledge of the Musical Arts in Traditional Society". In Anri Herbst, Meki Nzewi, Kofi Agawu (eds). Musical Arts in Africa. Pretoria: Unisa Press.

Oehrle, E and Emeka, L. 2003. 'Thought systems informing the musical arts'. In: Anri Herbst, Meki Nzewi and Kofi Agawu (eds). Musical Arts in Africa: Theory, Practice and Education. Pretoria: Unisa Press.

Orawo, C. N. 1998. 'Music education as a means of attaining insight in humanity'. In Caroline van Niekerk \& S. Torta (eds). 23rd ISME Selected Conference Proceedings: abstracts of paper, workshops and demonstrations, 142-148. Pretoria: Unisa press.

Van der Hooft, A. G. 1979. Die Malopodans. Amsterdam: Rodopi.

Walker, R. 1998. In Music Education "a hundred flowers blossom and a hundred schools of thought contend". Is this a Problem? International Journal of Music Education, Number 32, 53-59.

\section{KEY WORDS}

Thanksgiving

Songs

Pedi Society

Musical terminology

Christianization of African meta-religious powers

Indigenous Pedi practice

Author : Edward Lebaka

(Study leader: Dirk J Human)

Post-doctoral Fellow

Biblical and Religious Studies

Department of Old Testament Studies

University of Pretoria

Email: edwardlebaka@gmail.com

Dirk.human@up.ac.za 